\title{
Comment on Joyce and Razo-Garcia (2011): Reserves, quotas and the demand for international liquidity
}

\author{
Peter Bernholz
}

Published online: 6 April 2011

(C) Springer Science+Business Media, LLC 2011

In the present paper Joyce and Razo-Garcia (2011) explore whether there exists a relationship between the quotas countries enjoy with the IMF and their reserve policies. In doing so they are asking an interesting question which has until now been neglected. Their hypothesis is that the built-up of reserve holdings by central banks is the bigger the lower their quotas and thus the amount of financial support they could get.

After an introduction Section 2 explains the quota system of the IMF followed by the presentation of a simple "Model of Quotas and Reserves" in Section 3. It is assumed that reserves and the amounts available because of the quotas provide identical benefits, whereas the marginal costs of using the financial means provided by quotas are increasing in contrast to the constant costs of holding reserves. Moreover, the marginal costs of using these means are everywhere greater than those of using reserves as international liquidity. This is the case because of the conditions imposed by the IMF, "which in the short-run is contractionary if there are nominal rigidities in the economy." Here it is not clear to me why according to the model central banks should ever want to borrow from the IMF, if the marginal costs to do so are always higher than relying on own reserves.

I will return to this question in the end. Moreover, one might argue that the longrun should also be considered: Is it not true that the conditions imposed by the IMF are supposed to lead to a better economic situation for the borrowing country?

In Section 4 "Data and Methodology" are presented. A panel of 24 upper- and 29 middle-income countries is used for the years from 1970 to 2006. The latter nations are meant to represent the emerging countries. Whether this is fitting for some countries like Ecuador, Egypt and Pakistan may be not beyond doubt. I also do not see why gold is excluded from the reserves considered, especially since some central banks were active during the period in selling or buying gold. For instance, the

P. Bernholz $(\bowtie)$

Wirtschaftswissenschaftliches Zentrum (WWZ), Universitaet Basel, Basel, Switzerland

e-mail: Peter.Bernholz@unibas.ch 
Swiss National Bank sold more than half of its huge gold reserves in the years after 2000 and distributed the proceeds to the national and cantonal governments.

As a dependent variable Joyce and Razo-Garcia take the "natural logarithm of international reserves scaled by GDP measured in dollars." Next they look into the literature which provided several different explanations for reserve holdings by central banks: As a precautionary buffer stock for self-insurance against trade, financial and other shocks; as a consequence of export promotion by an undervalued exchange rate; to support the financial sector and to prevent unwanted depreciations of the currency. As a consequence they use in their empirical study (Imports + Exports)/GDP; the Chinn-Ito index (for financial openness); a dummy variable for fixed or pegged exchange rates; the deviation from purchasing power parity and M2/GDP for financial development as explanatory variables. Besides these, control variables like population, GDP per capita and terms of trade are included.

Their own innovation is, of course, "the inclusion of a country's IMF quota ... scaled initially by GDP, to determine whether there is an inverse relationship with foreign exchange reserves."

Finally period dummy variables are introduced as well as an indicator whether a country has participated in IMF programs "to determine whether [such] countries ... hold more or fewer reserves."

In Section 5 a bewildering wealth of results are presented with the help of four tables, which cannot be repeated here. They are partly contradictory if different sets of variables are included. But the result that lower quota (Q/GDP) with the IMF are connected with higher reserves remains significant for middle income countries. "... the behavior of advanced economies and emerging markets with respect to reserve holdings diverged after the East Asian crisis of 1997-98. Therefore, we estimate the model in Table 3 for only the middle income countries in our sample." In this case the authors find that "control, precautionary and stability variables generally continue to be significant." Moreover, "the argument that middle income economies hold more reserves in order to maintain an undervalued exchange rate" is confirmed. Finally it is interesting that participation in IMF programs "has a positive and significant coefficient in two equations."

Section 6 ends with some concluding remarks. Here we learn that the IMF has made its lending arrangements more appealing and increased the access limits. Still, even the authors conclude that in spite of these changes "It is unlikely ... that emerging markets will significantly reduce their demand for international reserves." Indeed, why should they, since according to the authors' model the marginal costs of doing so are always higher than those of getting international reserves. Unfortunately, Joyce and Razo-Garcia do not discuss why and under which conditions countries should borrow at all at the IMF. Obviously, given their assumptions this should only be the case if their reserves are exhausted and if they are no longer credit-worthy in international credit markets or have to pay such a risk premium on interest that it becomes cheaper or inescapable to borrow at the IMF. This means that only countries which are in a weak economic position would turn for help to the IMF. Others which undertook successful reforms were and are able to accumulate sufficient central bank reserves. This means that following Meltzer et al. (2000) the IMF should concentrate on supporting countries which are hit in a financial crisis by contagion without their own responsibility. 
More importantly, though the size of quota/GDP turns out to have a negative and significant influence on reserve holdings, one would have liked a discussion of the relative size of its influence compared to that of other independent variables. It is true that the authors have controlled their results by excluding China and obtained the same results. But still, it is difficult to imagine that quota/GDP should still have an influence on the further growth of China's huge reserves which are now by far surpassing those of the IMF. And for several other countries such a continuing influence seems also to be doubtful, given the level of reserves they have reached in recent years.

\section{References}

Joyce, J. P., \& Razo-Garcia, R. (2011). Reserves, quotas and the demand for international liquidity. Review of International Organizations 6, forthcoming.

Meltzer, A. H., et al. (2000). Report of the international financial institution advisory commission. Washington: GPO. 